\title{
Preparation and evaluation of herbal hair growth promoting shampoo formulation containing Piper betle and Psidium guajava leaves extract
}

\author{
Neelam Joshi', Kalpana Patidar², Rakesh Solanki ${ }^{2}$, Vandana Mahawar ${ }^{1}$ \\ ${ }^{1}$ Research Scholar, Master of Pharmacy, Mandsaur University, Mandsaur, Madhya Pradesh, India, ${ }^{2}$ Department \\ of Pharmaceutics, B. R. Nahata College of Pharmacy, Mandsaur, Madhya Pradesh, India
}

\begin{abstract}
Context: Antioxidants are helpful in increasing the blood circulation and thus help in hair growth as well as in the treatment of diseases. Alopecia is a dermatological disorder with psychosocial implications on patients with hair loss. The antioxidant property of plant and different herbs can be utilized in hair fall conditions or many diseases. Aim: The aim of this study is to develop an herbal hair growth promoting shampoo using Piper betle and Psidium guajava leaves extract due to their antioxidant property. Materials and Methods: Antioxidant activity of herbal shampoo formulation containing $P$. betle and $P$. guajava leaves extract was determined using 2, 2-diphenyl-1picrylhydrazyl (DPPH) method, $0.5 \mathrm{ml}$ of each sample at various concentrations was added to $1.5 \mathrm{ml}$ of DPPH $(0.004 \%)$ solution and allowed to stand in the dark at room temperature for $20 \mathrm{~min}$. The absorbance at $520 \mathrm{~nm}$ was recorded using UV spectroscopy which was compared with ascorbic acid taken as standard. Results: The results of the study demonstrated that formulation $\mathrm{FC}_{3}$ exhibited best antioxidant activity and formulation was stable for 2 months. The formulation $\mathrm{FC}_{3}$ shows better $\mathrm{pH}$, foamability, dirt dispersion, and wettability. Conclusion: The results of this study suggested that herbal shampoo formulation containing $P$. betle and $P$. guajava leaves extract is best for hair growth promoter and many problems related to hairs.
\end{abstract}

Key words: Antioxidants, hair fall, hair, herbal shampoo, Piper betle, Psidium guajava L.

\section{INTRODUCTION}

Hair

$\mathrm{H}$ air is one of the vital parts of the body derived from ectoderm of the skin, is protective appendages on the body. They are also known as epidermal derivatives as they originate from the epidermis during embryological development. ${ }^{[1]}$ Hair is a protein filament that grows from follicles found in the

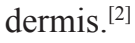

\section{Hair Fall}

Hair fall is the thinning of hair on the scalp. The medical term for hair fall is alopecia. Alopecia can be temporary or permanent. ${ }^{[3]}$ Hair fall is one of the most common complaints among all patients. ${ }^{[4]}$ Hair fall occurs due to following reasons such as physical stress, poor diet, especially less protein intake, excessive hair styling and coloring, taking excessive amounts of Vitamin A supplements, and Vitamin B deficiency. ${ }^{[5]}$ There are various types of hair growth promoters which help in not only reducing the hair fall conditions but also promotes the new growth of hairs, for example, Emblica officinalis (amla), Bacopa monnieri (brahmi), Ocimum sanctum (tulsi), and Nerium oleander (kaner). ${ }^{[6]}$

\section{Herbal Shampoo}

Natural cosmetics are popular one all over the world as they convey the impression of having better purity, safety, and

Address for correspondence:

Dr. Kalpana Patidar, Department of Pharmaceutics,

B. R. Nahata College of Pharmacy, Mandsaur - 458 001, Madhya Pradesh, India. Phone: +91-7024430030.

E-mail: kappharma@rediffmail.com

Received: 07-09-2018

Revised: 07-11-2018

Accepted: 28-11-2018 
efficacy. ${ }^{[7]}$ Herbal shampoo is a cosmetic preparation which uses herbs from plants and it is meant for washing of hair and scalp just like a regular shampoo. Herbalists, today, believe in helping people intended for build their good health with the help of natural sources. ${ }^{[8]}$

\section{Antioxidants}

Antioxidants are the substances that are used in small concentration and thus inhibit the process of oxidation. ${ }^{[9]}$ The physiological role of antioxidants is to prevent damage of cellular components arising as a consequence of chemical reactions involving free radicals. ${ }^{[10]}$

\section{Role of Antioxidants in Hair}

Antioxidants have been included in cosmetic formulations specially designed to reduce the adverse effects on hair fiber. ${ }^{[11]}$ Antioxidants are extremely beneficial in the prevention of hair loss as well as stimulating new, healthy hair growth. Some of the most powerful ones are green tea, blueberries, and grape seed extract. ${ }^{[12]}$

Piper betle belongs to the family Piperaceae. ${ }^{[13]}$ The betel plant is an evergreen and perennial creeper, with glossy heart-shaped leaves ${ }^{[14]}$ Betel leaves for hair loss are powerful because the content of polyphenols and flavonoids in betel leaf serves as an antioxidant and anti-inflammatory that can protect the hair from broken which is caused by inflammation of skin diseases and free radicals that cause hair loss on the head. ${ }^{[15]}$

Psidium guajava L. is a small medicinal tree that is inhabitant to South America. It is popularly known as guava (family: Myrtaceae).${ }^{[16]}$ Guava leaves strengthen the hair follicles, which promote thicker, stronger, shinier, and healthier hair growth. ${ }^{[17]}$ Guava leaves contain Vitamin C, which helps boost collagen activity. This helps hair grow out faster and healthier. Both betel and guava leaves are best known for hair growth promotes and their formulation is not prepared at all. Hence, the aim of this research article was to formulate a herbal shampoo for hair growth promoter containing betel and guava leaves extract. ${ }^{[18]}$

\section{MATERIALS AND METHODS}

\section{Collection of Plant Materials}

Betel leaves were purchased from the local market of Ratlam and guava leaves were collected from local region and both leaves were authenticated by Dr. S. N. Mishra (Head AINP on M and AP) KNK College of Horticulture, Mandsaur, M.P.

\section{Extraction Method}

\section{Extraction of betel leaves using distilled water as a} Solvent

Betel leaves were extracted using water as a solvent. The extraction was carried out using heating mantle and beaker of $1000 \mathrm{ml}$. Leaves were dried under shade and dried powder of leaves was used for extraction. About $30 \mathrm{~g}$ of powdered leaves were boiled with $900 \mathrm{ml}$ of water at $50^{\circ} \mathrm{C}$ to avoid degradation of phytochemical for $9 \mathrm{~h}$; extract was filtered through a muslin cloth and then dried by heating in water bath. ${ }^{[19]}$

\section{Extraction of guava leaves using distilled water as a solvent}

Guava leaves were extracted using water as a solvent. The extraction was carried out using heating mantle and beaker of $1000 \mathrm{ml}$. Leaves were dried under shade and dried powder of leaves was used for extraction sample of $50 \mathrm{~g}$ guava leaves in $1 \mathrm{~L}$ distilled water was boiled for $4 \mathrm{~h}$ at $100^{\circ} \mathrm{C}$. The sample was then filtered using muslin cloth and dried by heating in water bath [Figure 1]. ${ }^{[20,21]}$

\section{Procedure of Herbal Shampoo}

Mix water, oleic acid, and sodium lauryl sulfate and heat to $60^{\circ} \mathrm{C}$. Slowly add triethanolamine with continuous stirring. Add EDTA and methylparaben, after cooling to $35^{\circ} \mathrm{C}$ and finally add two drops of lavender oil for imparting fragrance in shampoo preparation [Table 1 and Figure 2]. ${ }^{[22]}$

\section{Antioxidant Activity of Formulated Shampoo Preparation}

The antioxidant activity of the formulation was examined on the basis of the scavenging effect and hydrogen donating

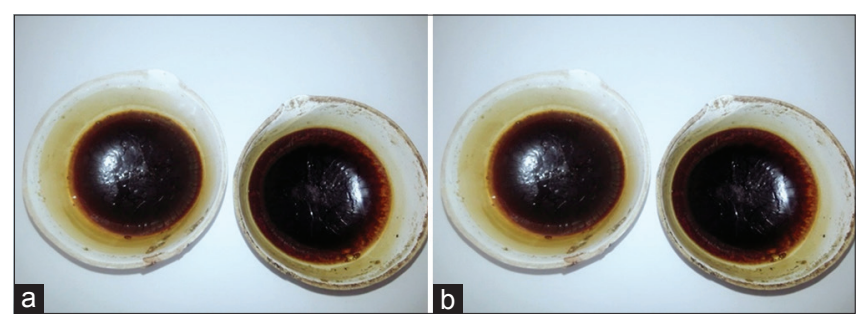

Figure 1: Extract of betel and guava leaves (a) Betel leaves extract, (b) Guava leaves extract

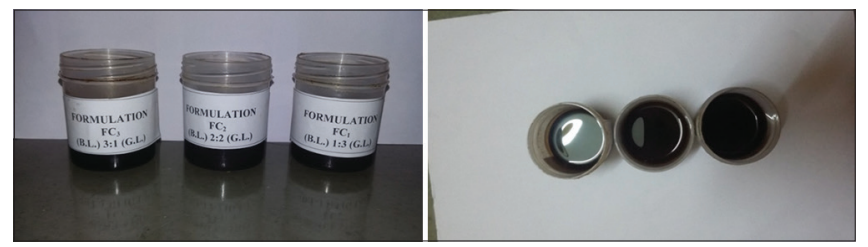

Figure 2: $(a$ and $b)$ Formulated herbal shampoo containing betel leaves and guava leaves extract 
ability on the stable 2, 2-diphenyl-1-picrylhydrazyl (DPPH) free radical and the absorbance was taken at $520 \mathrm{~nm}$ using UV spectrophotometer.

\section{Procedure of Sample Preparation}

About $10 \mathrm{mg} / \mathrm{ml}$ of shampoo formulation were weighed and prepared a sample solution using ethanol as a solvent and then filtered it and volume was makeup up to $10 \mathrm{ml}$ in volumetric flask. $0.5 \mathrm{ml}$ of each sample at various concentrations was added to $1.5 \mathrm{ml}$ DPPH (0.004\%) solution and allowed to stand in the dark at room temperature for $20 \mathrm{~min}$. The absorbance at $520 \mathrm{~nm}$ was recorded using UV spectroscopy and results are expressed in ascorbic acid equivalent/g dry weight of sample. The percentage of inhibition of DPPH free radical scavenging activity was calculated using the following equation:

$\%$ inhibition $=\frac{(\mathrm{A} \mathrm{DPPH}-\mathrm{A} \text { Sample })}{\mathrm{A} \mathrm{DPPH}} \times 100$

Where,

A DPPH $=$ Absorbance of DPPH

A sample $=$ Absorbance of sample (extract/ascorbic acid).

\section{Preparation of Standard (Ascorbic Acid)}

About $10 \mathrm{mg} / \mathrm{ml}$ of ascorbic acid was prepared in ethanol; then, $5 \mathrm{ml}$ of sample were taken and volume was makeup up to $50 \mathrm{ml}$ and different dilutions of different concentrations were prepared from this stock solution, that is, $20 \mu \mathrm{g} / \mathrm{ml}$, $40 \mu \mathrm{g} / \mathrm{ml}, 60 \mu \mathrm{g} / \mathrm{ml}, 80 \mu \mathrm{g} / \mathrm{ml}$, and $100 \mu \mathrm{g} / \mathrm{ml} .{ }^{[23,24]}$

\section{Evaluation Parameters of Shampoo}

\section{Physical appearance}

Formulation prepared was evaluated for the clarity, color, odor, and foam producing ability.

Table 1: Formulation of herbal shampoo in combination containing betel leaves and guava leaves extract

\begin{tabular}{lccc} 
Ingredients & $\mathbf{F C}_{1}$ & $\mathbf{F C}_{2}$ & $\mathbf{F C}_{3}$ \\
\hline Guava leaves extract $(\mathrm{g})$ & 3 & 2 & 1 \\
Betel leaves extract $(\mathrm{g})$ & 1 & 2 & 3 \\
Sodium lauryl sulfate $(\mathrm{g})$ & 8 & 8 & 8 \\
Triethanolamine $(\mathrm{ml})$ & 3.5 & 3.5 & 3.5 \\
Oleic acid (ml) & 4 & 4 & 4 \\
Methylparaben (g) & 0.25 & 0.25 & 0.25 \\
Lavender oil (Drops) & $2 \mathrm{ps}$ & 2 & 2 \\
EDTA & 0.15 & 0.15 & 0.15 \\
Water & Q.S. & Q.S. & Q.S. \\
\hline
\end{tabular}

\section{Determination of $\mathrm{pH}$}

The $\mathrm{pH}$ of $5 \% \mathrm{v} / \mathrm{v}$ shampoo solution in distilled water was measured using $\mathrm{pH}$ meter at room temperature or at $45^{\circ} \mathrm{C}$ temperature. ${ }^{[25]}$

\section{Dirt dispersion}

Two drops of shampoo were added in a large test tube contain $10 \mathrm{ml}$ of distilled water. One drop of India ink was added; the test tube was stoppered and shakes it 10 times. The amount of ink in the foam was estimated as none, light, moderate, or heavy. ${ }^{[26]}$

\section{Foaming ability and foam stability}

Cylinder shake method was used for determining foaming ability. $50 \mathrm{ml}$ of the $1 \%$ shampoo solution was put into a $100 \mathrm{ml}$ graduated cylinder and covered the cylinder with hand and shaken for 10 times. The total volumes of the foam contents after 1 min shaking were recorded. The foam volume was calculated only. Immediately after shaking the volume of foam at $1 \mathrm{~min}$ intervals for $4 \mathrm{~min}$ was recorded. ${ }^{[27]}$

\section{Stability study}

The stability study was carried out for the prepared shampoo at standard room temperature of $25-45^{\circ} \mathrm{C}$ for 2 months. ${ }^{[28]}$

\section{RESULTS AND DISCUSSION}

\section{Antioxidant Activity}

Antioxidant activity of the shampoo formulation was determined using DPPH method. The percentage inhibition was calculated in herbal formulation which contains betel leaves and guava leaves extract in combination of different concentrations $\mathrm{FC}_{1}(1: 3)$ that contains betel leaves:guava leaves), $\mathrm{FC}_{2}(2: 2)$ (betel leaves:guava leaves), and $\mathrm{FC}_{3}(3: 1)$ (betel leaves:guava leaves) formulations were showed $66 \%, 72 \%$, and $88 \%$ inhibition, respectively, as compared to ascorbic acid which was taken as standard of different concentrations $(20 \mu \mathrm{g} / \mathrm{ml}, 40 \mu \mathrm{g} / \mathrm{ml}, 60 \mu \mathrm{g} / \mathrm{ml}, 80 \mu \mathrm{g} / \mathrm{ml}$, and $100 \mu \mathrm{g} / \mathrm{ml}$ ) that show $48 \%, 62 \%, 69 \%, 76 \%$, and $79 \%$ inhibition. From this percentage inhibition, combination formulation of $\mathrm{FC}_{3}$ shows better inhibition [Graphs 1 and 2].

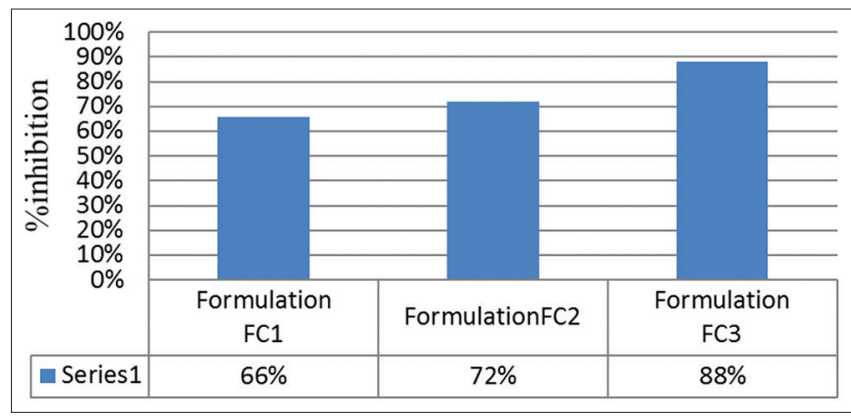

Graph 1: 2, 2-diphenyl-1-picrylhydrazyl scavenging activity of shampoo formulation 
Joshi, et al.: Preparation and evaluation of an herbal hair growth promoting shampoo

\begin{tabular}{llllll}
\multicolumn{7}{c}{ Table 2: } & Physical parameters of $\mathrm{FC}_{3}$ formulation & & \\
Formulation & Color & Odor & Texture & State & Grittiness \\
\hline $\mathrm{FC}_{3}$ & Dark brown & Characteristic & Smooth & Liquid & No grittiness \\
\hline
\end{tabular}

\begin{tabular}{lclllll}
\multicolumn{7}{c}{ Table 3: Stability optimization of herbal shampoo formulation } \\
Days & Temperature & Appearance & Odor & Foamability & pH & Dirt dispersion \\
\hline Initial days & $4^{\circ} \mathrm{C}$ & Dark brown & Characteristic & Good & 4.7 & Light \\
& At room temperature & Dark brown & Characteristic & Good & 5.2 & Light \\
& $45^{\circ} \mathrm{C}$ & Dark brown & Characteristic & Good & 5 & Light \\
After 30 days & $4^{\circ} \mathrm{C}$ & Dark brown & Characteristic & Good & 4.9 & Light \\
& At room temperature & Dark brown & Characteristic & Good & 5.3 & Light \\
& $45^{\circ} \mathrm{C}$ & Dark brown & Characteristic & Good & 5.1 & Light \\
After 60 days & $4^{\circ} \mathrm{C}$ & Dark brown & Characteristic & Good & 4.8 & Light \\
& At room temperature & Dark brown & Characteristic & Good & 5.2 & Light \\
& $45^{\circ} \mathrm{C}$ & Dark brown & Characteristic & Good & 5.1 & Light \\
\hline
\end{tabular}

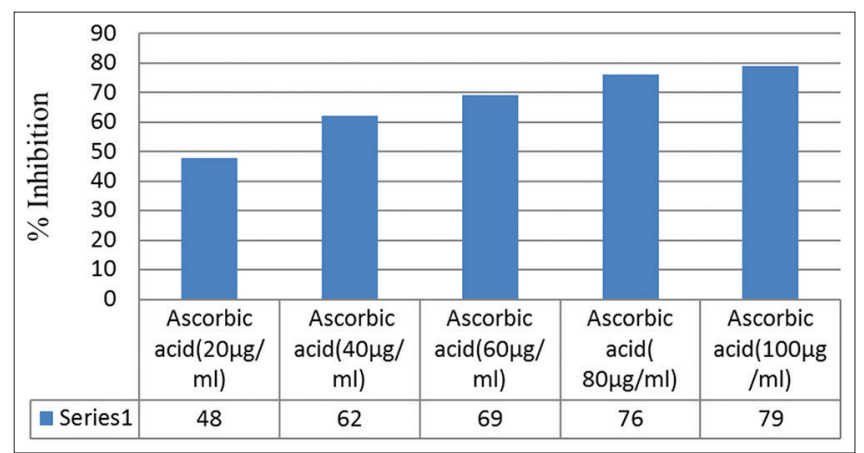

Graph 2: 2, 2-diphenyl-1-picrylhydrazyl scavenging activity of ascorbic acid

\section{Evaluation Parameters of Herbal Shampoo}

\section{Physical properties}

Physical properties of combination formulation $\mathrm{FC}_{3}$ are shown in Table 2.

\section{Stability studies}

All the physicochemical parameters were well maintained during the period of accelerated stability studies at temperatures $4^{\circ} \mathrm{C}$ in refrigerator and at $25^{\circ} \mathrm{C}$ and $45^{\circ} \mathrm{C}$ in incubator for 2 months. Formulation $\mathrm{FC}_{3}$ shows good stability in color, odor, foamability, and consistency until the end of accelerated study [Table 3].

\section{CONCLUSION}

At present, time herbal cosmetic has been marked up in personal care system and there is a great requirement for the herbal cosmetics in daily life. In this research article, formulate an herbal anti-hair fall and hair growth promoting shampoo containing betel leaves and guava leaves extract.
Formulation was prepared containing betel leaves and guava leaves extract of different concentrations in combination and antioxidant activity was determined by taking ascorbic acid as standard. The percentage inhibition of a combination formulation $\mathrm{FC}_{3}$ shows $88 \%$ as compared to ascorbic acid which shows $79 \%$ inhibition of DPPH and formulation was evaluated for general parameters such as $\mathrm{pH}$, dirt dispersions, and appearance and it was stable for 2 months and it is best for the hair fall conditions, alopecia, because betel leaves and guava leaves are best for reducing hair fall or hair growth promoter and show best antioxidant activity and their combination formulation is not available in the market at now. A need for this age is to prepare herbal cosmetics which will prove beneficial and has lesser side effects.

\section{REFERENCES}

1. Singh K, Saeed F, Ahmad Z, Ahsan F, Shakya P. Alopecia: Introduction and overview of herbal treatment. J Chem Pharm Res 2016;8:59-64.

2. Available from: https://www.en.wikipedia.org/wiki/ Hair. [Last accessed on 2018 Jul 29].

3. Available from: https://www.medicinenet.com/script/ main/art.asp?articlekey $=53390$. [Last accessed on 2018 Aug 03].

4. Katlein F, Rodrigues ST, Ledon J, Savasi J, Chacom A. Comprehensive overview and treatment update on hair loss. J Cosmet Dermat Sci App 2013;3:1-8.

5. Available from: https://www.practo.com/health-wiki/ hair-lossalopecia-causes-symptoms-and-treatment/89/ article. [Last accessed on 2018 Aug 02].

6. Patel S, Sharma V, Chauhan NS, Thakur M, Dixit VK. Hair growth: Focus on herbal therapeutic agent. Curr Drug Discov Tech 2015;12:1-22. Available from: https:// www.researchgate.net/profile/Nagendra_Chauhan/ publication/278045537_Hair_Growth_Focus_on_Herbal_ 
Therapeutic_Agent/links/55af72fd08ae6aa568b3a960/ Hair-Growth-Focus-on-Herbal-Therapeutic-Agent.pdf. [Last accessed on 2018 Aug 02].

7. Shinde PR, Tatiya AU, Surana SJ. Formulation development and evaluation of herbal antidandruff shampoo. Int J Res Cosmet Sci 2013;3:25-33.

8. Mahendran S, Noordin HA. Formulation and evaluation of herbal shampoo containing rambutan leaves extract. Int J Pharm Bio Sci 2016;7:146-51.

9. Kumar S. The importance of antioxidant and their role in pharmaceutical sciences-a review. Asian J Res Chem Pharm Sci 2014;1:27-44.

10. Young IS, Woodside JV. Antioxidants in health and disease. J Clin Pathol 2001;54:176-86.

11. Fernández E, Martínez-Teipel B, Armengol R, Barba C, Coderch L. Efficacy of antioxidants in human hair. J Photochem Photobiol B 2012;117:146-56.

12. Available from: https://www.newbeauty.com/blog/ dailybeauty/7198-antioxidants-the-answer-to-agingstrands. [Last accessed on 2018 Aug 02].

13. Dwivedi V, Tripathi S. Review study on potential activity of Piper betle. J Pharmacogn Phytochem 2014;3:93-8.

14. Palaniappan G, Sengottiyan A, Sravanan T. Betel leaf: The green gold of India. Facts 2012;2:21-4. Available from: http://www.efy.efymag.com.>BetelLeaf-April-12. [Last accessed on $2018 \mathrm{Jul} 30$ ].

15. Available from: http://www.greenlifehealthy.com/ benefits-of-betel-leaf. [Last accessed on 2018 Jul 30].

16. Alvares GR, Brunnati CS, Ottoboni MB, Nicolau CT. Psidium guajava (Guava): A plant of multipurpose medicinal applications. Med Aromat Plants 2012;1:1-6. Available from: https://www.researchgate.net/ publication/269549051_Psidium_guajava_Guava_A_ Plant_of_Multipurpose_Medicinal_Applications. [Last accessed on 2018 Aug 02].

17. Available from: https:/www.hairlossable.com/guavaleaves-can-help-hair-grow. [Last accessed on 2018 Aug 02].

18. Available from: http://www.stylecraze.com/articles/ how-are-guava-leaves-beneficial-for-your-hair/\#gref. [Last accessed on 2018 Aug 02].
19. Pin KY, Chuah AL, Rashih AA, Mazura MP, Fadzureena J, Vimala S, Rasadah MA. Antioxidant and anti-inflammatory activities of extracts of betel leaves (Piper betle) from solvents with different polarities. J Trop Forest Sci 2010;22:448-55.

20. Seo J, Soojung L, Marcus LE, Sarah AJ, Kang J, Bahram HA. Study to find the best extraction solvent for use with guava leaves (Psidium guajava L.) for high antioxidant efficacy. Food Sci Nutr 2014;2:174-80.

21. Noer L, Retno WK, Iim S, Maria RD. The Potency of guava Psidium guajava (L.) leaves as a functional immune stimulatory ingredient. Procedia chem 2015; 14:301-7.

22. Mithal BM, Saha RN. A handbook of cosmetics. Vallabh prakashans 2013;9:119.

23. Veeru P, Mishra PK, Mishra M. Screening of medicinal plant extracts for antioxidant activity. J Med Plants Res 2009;3:608-12.

24. Yadav NK, Arya RK, Dev K, Sharma C, Hossain Z, Meena $\mathrm{S}$, et al. Alcoholic extract of Eclipta alba shows in vitro antioxidant and anticancer activity without exhibiting toxicological effects. Hindawi Oxid Med Cell Longev 2017;18:1-8.

25. Badi KA, Khan AH. Formulation, evaluation and comparison of the herbal shampoo with the commercial shampoos. J Basic and Applied Sci 2014;3:301-5.

26. Dessai P, Phatarpekar S. Formulation and evaluation of herbal shampoo and to compare formulated shampoo with marketed shampoos. World J Pharm Pharm Sci 2016;5:1467-77.

27. Kumar A, Mali RR. Evaluation of prepared shampoo formulations and to compare formulated shampoo with marketed shampoos. Int J Pharm Sci 2010;3:120-6.

28. Mendhekar YS, Tajane AS, Shitole BP, Jadhav SL Gaikwad DD. Formulation and evaluation of polyherbal shampoo and compared with marketed shampoo. World J Pharm Pharm Sci 2017;6:1388-97.

Source of Support: Nil. Conflict of Interest: None declared. 